\title{
PELATIHAN PENYUSUNAN ANGGARAN UNTUK UMKM DI DESA BUMI JAYA
}

\section{Ines Saraswati Machfiroh ${ }^{1)}$, Noor Ameliaa ${ }^{2)}$, Radna Nurmalina ${ }^{3)}$, Tekad B ${ }^{4)}$ ${ }^{122) 34)}$ Program Studi Akuntansi, Politeknik Negeri Tanah Laut}

Jl. A. Yani, Km 6, Ds. Panggung, Kec. Pelaihari, Kab. Tanah Laut, Kalimantan Selatan Email: ${ }^{1)}$ inessaraswati.m@gmail.com

${ }^{2)}$ noor.amelia2012@gmail.com

${ }^{3)}$ radnanurmalina@yahoo.co.id

4) tekad@politala.ac.id

\begin{abstract}
Abstrak: Kegiatan pengabdian kepada masyarakat $(\mathrm{PkM})$ merupakan salah satu Tri Dharma Perguruan Tinggi, selain pendidikan, pengajaran, penelitian dan pengembangan yang wajib dilakukan oleh civitas akademik suatu perguruan tinggi. Melalui pengabdian kepada masyarakat, Program Studi Akuntansi Politeknik Negeri Tanah Laut hadir ditengah-tengah masyarakat khususnya di Kabupaten Tanah Laut. Hal tersebut bertujuan untuk mengaplikasikan hasil pembelajaran dan penelitian di perkuliahan dan memberikan informasi kemajuan ilmu pengetahuan yang bermanfaat bagi masyarakat. Penerapan ilmu akuntansi yang kerap diterapkan dalam kasus ini mengenai pelatihan penyusunan anggaran untuk UMKM (Usaha Mikro Kecil Menengah). Kegiatan Pelatihan Penyusunan Anggaran untuk UMKM dihadiri oleh peserta yang berjumlah 15 orang yang berasal dari pelaku UMKM. Kegiatan ini dibagi menjadi dua tahap yakni penjelasan tentang penyusunan anggaran untuk UMKM secara umum dan tanya jawab peserta. Dengan adanya ilmu mengenai hal ini, masyarakat desa khususnya pelaku UMKM dalam melakukan penyusunan anggaran untuk UMKM diharapkan dapat menyusun anggaran secara tepat. Hasil dari kegiatan ini adalah masyarakat desa khususnya pelaku UMKM memperoleh informasi tambahan mengenai menyusun anggaran untuk UMKM. Selain itu, pemateri maupun peserta saling berbagi pengalaman dalam menyelesaikan permasalahan yang terjadi dalam penyusunan anggaran untuk UMKM.
\end{abstract}

Kata Kunci: Pelatihan, Peyusunan, Anggaran, UMKM

\section{PENDAHULUAN}

Usaha Mikro Kecil Menengah (UMKM) di Indonesia merupakan salah satu soko guru perekonomian Indonesia selain koperasi. Hal ini dapat terlihat dari bukti nyata bahwa sebagian besar UMKM di Indonesia tidak menghadapi krisis di tengah-tengah krisis global pada tahun 2008 lalu. Perkembangan jumlah UMKM dari tahun ke tahun semakin bertambah. Namun untuk aspek finansial, hanya sedikit UMKM yang mengalami perkembangan dalam hal kinerja keuangannya. Hal ini tak lepas dari ketidaksadaran pelaku UMKM terhadap pentingnya menyusun anggaran.

Penyusunan anggaran menjadi salah satu aspek penting bagi kemajuan UMKM. Perencanaan anggaran dapat dilakukan melalui akuntansi. Akuntansi merupakan proses sistematis untuk menghasilkan informasi 
keuangan yang dapat digunakan untuk pengambilan keputusan bagi penggunanya. Akuntansi akan memberikan beberapa manfaat bagi pelaku UMKM, antara lain: (1) UMKM dapat mengetahui kinerja keuangan perusahaan, (2) UMKM dapat mengetahui, memilah, dan membedakan harta perusahaan dan harta pemilik, (3) UMKM dapat mengetahui posisi dana baik sumber maupun penggunaannya, (4) UMKM dapat membuat anggaran yang tepat, (5) UMKM dapat menghitung pajak, dan (6) UMKM dapat mengetahui aliran uang tunai selama periode tertentu. Melihat manfaat yang dihasilkan akuntansi, pelaku UMKM seharusnya sadar bahwa akuntansi penting bagi perusahaan mereka. Penggunaan akuntansi dapat mendukung kemajuan UMKM khususnya dalam hal keuangan yang berkaitan dengan anggaran. Namun, masih banyak UMKM yang belum menggunakan akuntansi dalam menunjang kegiatan bisnisnya. Alasan pelaku UMKM tidak menggunakan akuntansi antara lain adalah akuntansi dianggap sesuatu yang sulit dan tidak penting.

Banyak pelaku UMKM merasa bahwa perusahaan mereka berjalan normal namun sebenarnya UMKM tersebut tidak mengalami perkembangan. Ketika mereka mendapatkan pertanyaan mengenai penyusunan anggaran yang direncanakan setiap periode, mereka tidak bisa menunjukkan dengan nominal angka melainkan dengan keuntungan (aset). Pelaku UMKM merasa kesulitan jika harus menggunakan akuntansi dalam kegiatan bisnisnya. Hal ini dikarenakan tidak adanya pedoman atau buku yang dapat dijadikan referensi untuk belajar menyusun anggaran untuk UMKM. Buku-buku yang beredar saat ini memang belum ada yang fokus pada penyusunan anggaran untuk UMKM.

Berdasarkan latar belakang tersebut, maka perlu dilakukan adanya pelatihan penyusunan anggaran untuk UMKM di Desa Bumi Jaya. Adapun tujuan dari kegiatan pelatihan ini adalah penerapan ilmu pengetahuan mengenai tugas pelaku UMKM dalam melakukan penyusunan anggaran. Dengan harapan pelaku UMKM dapat melakukan penyusunan anggaran secara tepat.

\section{METODE PELATIHAN PENYUSUNAN ANGGARAN UNTUK UMKM}

Kegiatan pengabdian kepada masyarakat berupa Pelatihan Penyusunan Anggaran oleh pelaku UMKM, dilaksanakan di Desa Bumi Jaya. Kegiatan dilaksanakan pada tanggal 30 April 2018 bertempat di Balai Desa Bumi Jaya. Kegiatan Pelatihan Penyusunan Anggaran untuk UMKM dihadiri oleh peserta yang berjumlah 15 orang yang berasal dari pelaku UMKM. Kegiatan ini dibagi menjadi dua tahap yakni penjelasan tentang 
penyusunan anggaran untuk UMKM secara umum dan tanya jawab peserta.

Pada tahap penjelasan, peserta diberi wawasan tentang penyusunan anggaran yang sesuai dengan peraturan akuntansi. Peserta diberikan informasi tentang cara memahami menyusun anggaran yang dilakukan oleh pelaku UMKM secara tepat, yaitu dengan menyajikan diagram mengenai perencanaan keuangan untuk UMKM dan strategi keuangan yang bisa diterapkan pada UMKM.

Diagram 1 Perencanaan Keuangan untuk UMKM

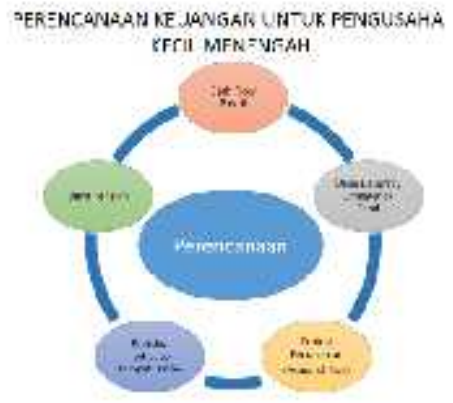

Diagram 2 Strategi Keuangan yang Bisa Diterapkan Pada Usaha Bisnis Kecil

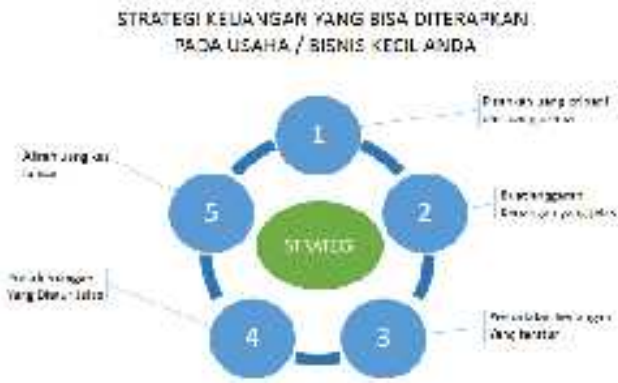

Dari ke dua diagram di atas pemateri menjelaskan satu per satu bagian yang ada di dalam diagram tersebut kepada pelaku UMKM, dengan harapan para pelaku UMKM yang ikut pelatihan ini dapat mengetahui bagaimana perencanaan keuangan yang tepat dan strategi keuangan yang bisa diterapkan pada UMKM mereka.

Gambar 1 Pemateri memberikan Materi kepada Peserta

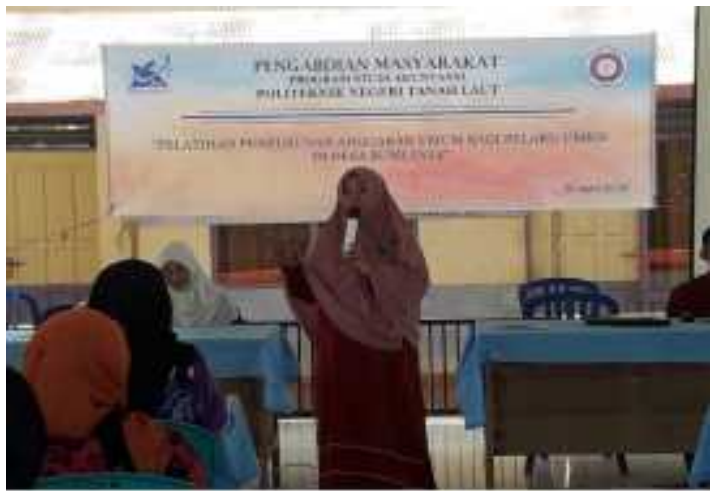

Setelah selesai sesi pemaparan materi hingga tanya jawab oleh peserta, maka berakhir pula kegiatan pengabdian kepada masyarakat. Kemudian dilakukan sesi foto bersama antara Pelaku UMKM dan Dosen Prodi Akuntansi serta antara Dosen Prodi Akuntansi dan Mahasiswa.

\author{
Gambar 2 Foto Bersama Pelaku UMKM \\ dengan Dosen Prodi Akuntansi
}




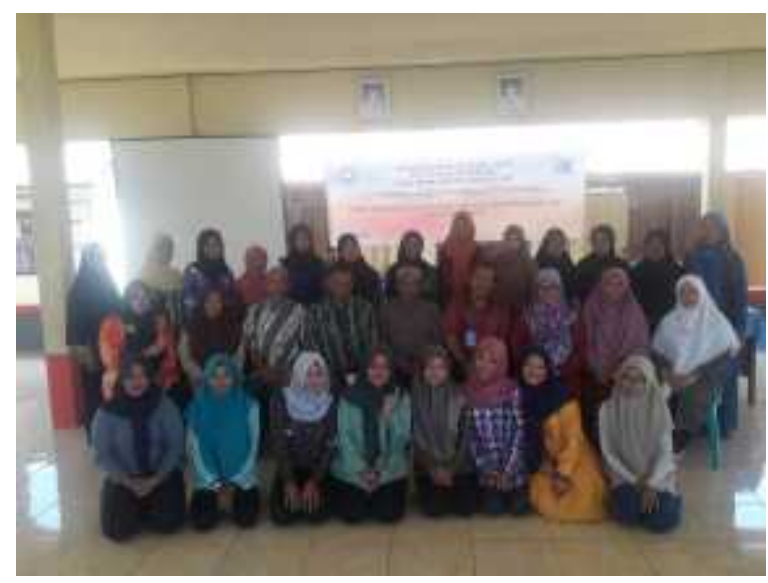

Gambar 3 Foto Bersama Dosen Prodi Akuntansi dengan Mahasiswa

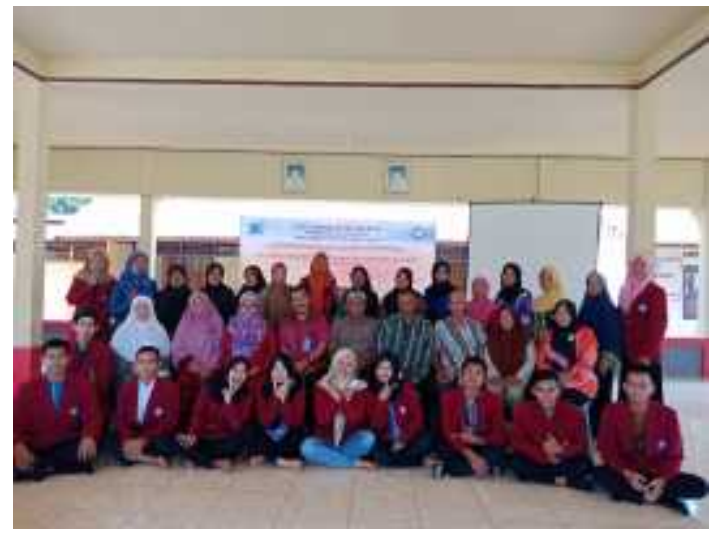

\section{HASIL EVALUASI KEGIATAN}

Selama proses pelaksanaan terdapat beberapa hal yang berjalan diluar perencanaan, diantaranya sebagai berikut :

1. Pelatihan dilakukan setelah peserta mengikuti proses pemberian materi sehingga ketika mengikuti pelatihan peserta terlihat lelah. Hal ini berdampak pada keaktifan peserta selama pelatihan. Meski terdapat beberapa peserta yang aktif namun sebagian besar masih pasif. Harusnya untuk membuat nuansa pelatihan yang lebih aktif dan kondusif, pemateri memberikan selingan berupa games. Namun hal ini tidak dilakukan pemateri karena waktu yang terlalu singlat yang diberikan oleh pihak desa.

2. Singkatnya waktu pelatihan yang juga berdampak pada pemberian materi. Pada pelaksanaan, materi yang diberikan melalui satu arah (dari pemateri ke peseerta) sehingga kurang ada konfirmasi pengetahuan atau pemahaman peserta akan materi pelatihan. Dampak yang lain adalah kurangnya peserta pelatihan melakukan latihan dalam mengaplikasikan materi pelatihan secara individu maupun kelompok.

\section{KESIMPULAN}

Hasil dari kegiatan ini adalah pihak pelaku UMKM memperoleh informasi tambahan mengenai penyusunan anggaran sesuai dengan ketentuan akuntansi yang berlaku. Selain itu, pemateri maupun peserta saling berbagi pengalaman dalam menyelesaikan permasalahan yang terjadi dalam penyusunan anggaran.

\section{DAFTAR PUSTAKA}

Endra Murti Sagoro. 2012. Akuntansi Tanpa Stres. Yogyakarta: AB Publiser.

Sony Warsono. 2009. Akuntansi ternyata Logis dan Mudah. Yogyakarta: Asgard Chapter 